\title{
Short-Term Experience in Cochlear Implantation with Slim Modiolar Electrode Array (CI532): Comparison to Previous Devices
}

\author{
Jin Taek Park, Min Young Kwak, Yehree Kim, Jee Yeon Lee, Woo Seok Kang, \\ Joong Ho Ahn, Jong Woo Chung, and Hong Ju Park \\ Department of Otolaryngology-Head and Neck Surgery, Asan Medical Center, University of Ulsan College of Medicine, Seoul, Korea
}

\author{
와우축을 감싸는 가는 전극을 가진 CI532 기기를 이용한 인공와우 수술의 단기 경험: \\ 기존의 기기와의 비교
}

박진택 · 곽민영 · 김예리 · 이지연 · 강우석 · 안중호 · 정종우 · 박홍주

울산대학교 의과대학 서울아산병원 이비인후과학교실

Received October 16, 2019

Revised March 30, 2020

Accepted May 13, 2020

Address for correspondence

Hong Ju Park, MD, PhD

Department of Otorhinolaryngology-

Head and Neck Surgery,

Asan Medical Center,

University of Ulsan

College of Medicine,

88 Asanbyeongwon-gil, Songpa-gu,

Seoul 05505, Korea

Tel +82-2-3010-3700

Fax +82-2-489-2773

E-mail dzness@hotmail.com
Background and Objectives There have been no reports in Korea regarding cochlear implant surgeries using Cochlear Nucleus Profile Slim Modiolar electrode [CI532 (Cochlear Ltd.)], as it has been recently released in Korea. We aimed to investigate the short-term results of CI532 and compare them with previous devices with perimodiolar or straight electrodes arrays from the same manufacturer.

Subjects and Method From August 2018 to July 2019, 52 patients (26 adults; 26 children) who underwent cochlear implantation of CI532 were included. The intraoperative impedance and evoked compound action potential (ECAP) threshold in each electrode were analyzed and compared with the devices with a perimodiolar electrode array [Contour Advance ${ }^{\circledR}$ (Cochlear Ltd.)] and a lateral wall electrode array [CI422 and CI522 (Cochlear Ltd.)]. Postoperative changes of hearing thresholds at each frequency $(250,500$, and $1000 \mathrm{~Hz})$ and aided word recognition scores (WRS) were also compared.

Results CI532 showed significantly lower intraoperative impedance in the basal regions compared to the lateral wall electrode array. The ECAP thresholds of CI532 in the apical electrodes were significantly lower than that in the other two groups. After implantation, CI532 showed a significant preservation of hearing thresholds at most frequencies and showed significantly higher preservation rates than the other electrodes. However, there was no difference between the three groups regarding the postoperative short-term aided WRS.

Conclusion CI532 showed lower intraoperative impedances and ECAP thresholds, and better short-term hearing preservation outcomes compared to the other electrodes, suggesting that CI532 electrode might be a better option with less traumatic insertion. However, there was no significant difference in the aided WRS, and further studies with a longer follow-up are necessary to examine the difference of audiologic outcomes.

Korean J Otorhinolaryngol-Head Neck Surg 2021;64(4):223-31

Key Words Cochlear implant · Deafness $\cdot$ Electrodes $\cdot$ Hearing loss $\cdot$ Perception $\cdot$ Speech.

This is an Open Access article distributed under the terms of the Creative Commons Attribution Non-Commercial License (https://creativecommons.org/licenses/by-nc/4.0) which permits unrestricted non-commercial use, distribution, and reproduction in any medium, provided the original work is properly cited. 


\section{서 론}

지난 수십 년 간 인공와우 이식술은 심도 및 고도 감각신 경성 난청 환자들의 청각 재활을 위한 유일한 대안으로 자리 매김하였다. 1970년대에 첫 다채널 인공와우 이식수술의 도 입 이후, 난청 환자의 말소리 지각(speech perception) 및 소 아에서의 언어 능력 향상을 위해 끊임없는 연구와 새로운 전 극 배열 기술 및 기기의 개발이 이루어져 왔다. ${ }^{1-4)}$ 또한 수술 술식 및 와우 접근 방식이 발전되어 왔고, 특히 잔여 청력이 있는 난청 환자에서는 무외상성(atraumatic) 전극 삽입을 통 해 잔청을 보존하려는 노력이 시도되고 있다. ${ }^{5-7)}$

최근의 인공와우 전극은 크게 제작된 모양에 따라 와우축 에 근접하게 위치하도록 곡선형으로 제작된 전극(perimodiolar electrode array, PM)과 일직선 형태로 만들어져 와우 고 실계의 측벽을 따라 전극이 위치하는 전극(lateral wall electrode array, LW)의 두 가지로 분류할 수 있다. PM형 전극은 전극이 와우축을 감싸도록 곡선형의 형태로 만들어져서 나 선형 신경절 세포(spiral ganglion cell)를 더욱 가까이서 자극 하는 것이 가능하고, 이를 통해 자극 역치를 낮추고 더 넓은 역동 범위(dynamic range)를 가질 수 있게 되어, 더욱 국소화 된 자극과 향상된 어음 인지력 결과를 얻는 것이 가능하다. ${ }^{8-10}$ 기존에 사용되던 PM형 전극 형태를 가진 CI24RE Contour Advance(Cochlear Ltd., Sydney, Austrailia)의 전극은 와우 축에 근접하는(modiolar-hugging) 형태로 제작되어 전극이 와우 신경에 더 가까이 위치하여 국소화된 자극을 줄 수 있 는 이점이 있고 부드러운 팁으로 최소한의 삽입 외상(minimal insertion trauma)을 줄 수 있는 것으로 알려져 있다. ${ }^{11,12}$ 이에 반하여 LW 형태의 전극은 공동(common cavity)과 같 은 와우축이 없는 내이 기형이 동반된 형태에서 와우의 외측 벽을 따라 삽입됨으로써 전기적 자극이 가능하도록 한다. ${ }^{13)}$ 이외의 내이 기형 또는 와우 골화가 일부 진행된 상황에서 perimodiolar형 전극에 비해 적절한 전극 삽입이 가능하도 록 하는 이점이 있다. ${ }^{14)}$ 이는 부드러운 팁을 포함하여 얇은 지 름(thin diameter), 정점 유연성(apical flexibility) 및 부드러운 외측 벽면(soft lateral wall surface)을 지니고 있어 전극 삽입 외상을 최소한으로 하는 것이 가능한 것으로 알려져 있다.

최근에 개발된 PM 형태의 전극인 CI532(Cochlear Ltd.) 전 극(Slim Modiolar electrode array)(Fig. 1)은 기존의 PM 전 극 형태의 이점과 함께 기존의 상대적으로 굵은 전극의 단점 을 극복하여 가늘게 제작되어 무외상성 전극 삽입이 더욱 용 이한 것으로 보고된다. ${ }^{15,16)} \mathrm{CI} 532$ 는 유럽의 경우 2015년 9월, 북미 지역은 2016년 3월에 최초 허가 승인이 이루어진 데 반 해, 국내에서는 2018년 4월부터 식약처 허가가 이루어졌고,

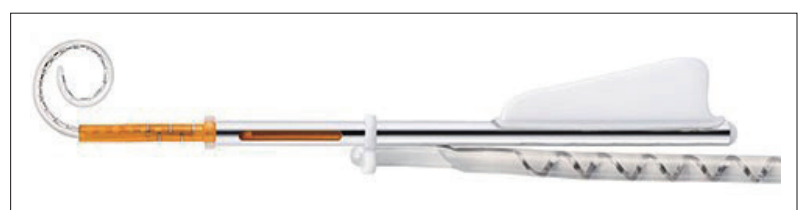

Fig. 1. The $\mathrm{Cl} 532$ Slim Modiolar Electrode is a thin full length perimodiolar electrode.

고심도 난청 환자를 포함하여 인공와우 이식술이 필요한 환 자들에게 현재 활발하게 사용되고 있다. ${ }^{17)}$ 따라서, 본 연구에 서는 최근 시행한 CI532를 이용한 인공와우수술의 수술 시 소견과 전기생리학적 결과 및 수술 후 단기 결과를 분석하고, 동일한 제조회사에서 제작된 $\mathrm{PM}$ 전극과 $\mathrm{LW}$ 전극을 가진 기존에 사용하였던 인공와우 기기를 사용한 환자에서의 결 과와 비교 분석하고자 하였다.

\section{대상 및 방법}

\section{대 상}

2018년 8월 2019년 7월까지 서울아산병원에서 CI532를 이 용하여 인공와우 이식술을 시행받은 52예(26명 성인, 26명 소 아)를 대상으로 하였다. 환자는 내이 기형을 가진 경우가 12예, 정상 내이 구조를 가진 경우가 40예(23명 성인; 17명 소아)였 다. 기존에 사용한 인공와우 기기와의 전기생리학적 검사 결 과의 비교를 위해, 정상 내이 구조를 가진 환자 40예와 과거에 같은 PM 형태인 CI24RE Contour Advance(이하 CA군)로 인공와우 수술을 시행받은 40 명의 환자(21명의 성인, 19 명의 소아)와 LW형인 CI422 또는 CI522(Cochlear Ltd.)(이하 LW 군)를 사용하여 수술받은 39명의 환자(16명의 성인, 23명의 소아)를 비교 대상에 포함하였다. 본 연구는 후향적 차트 리 뷰를 통해 정보를 수집하였다. 본 연구의 모든 과정은 본 연 구기관의 윤리위원회의 승인(IRB No. 2017-0589)을 통해 이 루어졌다.

\section{수술 관련 인자}

수술 술식과 관련하여, 모든 환자는 전통적인 유양돌기 절 제술 및 후고실개방술을 통해 인공와우 이식술을 시행받았 다. 와우 접근법으로는 정원창 접근법 또는 와우개창술로 진 행되었고, 접근법은 수술 중 주의 깊은 수술 부위 관찰을 통 해 정원창의 위치에 따라 또는 술자의 선호도 등에 의해 결정 되었다. 수술장 내에서 전극의 삽입 직후에 어음처리기를 부 착하여 임피던스 값과 유발복합활동전위(evoked compound action potential, ECAP)의 역치값을 분석하였으며, 임피던 스 $(\mathrm{kOhms})$ 는 Monopolar 1+2(MP1+2)로 기록, ECAP 역치 (current level)는 각 활성 전극에서의 Auto Neural Response 
Telemetry $\left(\mathrm{NRT}^{\mathrm{TM}}\right)$ (Cochlear Ltd.) 기능에 의해 정해지는 값을 기록하였다. ${ }^{18,19)} \mathrm{MP} 1+2$ 는 와우내 및 와우외(intracochlear \& extracochlear) 전극의 상태를 모두 반영할 수 있는 ECAP 측정 방식이고 AutoNRT ${ }^{\mathrm{TM}}$ 는 Nucleus 인공와우 시 스템에서 개발한 $\mathrm{ECAP}$ 을 자동적으로 측정해내는 알고리즘 이다. 임피던스의 경우, 과거 기종인 CA와 일부 CI422/522의 데이터가 기록으로 남아있지 않아, CI422/522 14예와 CI532 40예의 결과를 비교 분석하였다.

\section{청력 평가}

청력검사 결과는 수술 전 순음청력검사와 수술 3개월 후 순음청력검사 및 술후 일음절 단어인지점수(aided monosyllabic word recognition score, aided WRS) 결과를 이용하여 분석하였다. 청력 잔존비율의 평가 대상은 수술 당시 나이가 만 18세 이상이고 수술 전 잔존 청력이 있는 환자로 하였고, 수술 전 순음청력검사 상 모든 주파수 상에서 반응이 없는 환 자는 제외하였다. 상기 기준에 부합하는 환자는 CA군, $\mathrm{LW}$ 군, CI532군 각각 18 명, 12 명, 12 명에 해당하였다. 수술 후 잔존 청력에 대한 평가는 2 가지 방식으로 진행하였는데, 첫 번째 방 식(method 1)은 수술 후 순음청력검사 상 $250,500,1000 \mathrm{~Hz}$ 에 해당하는 청력 역치의 평균과 수술 전 $250,500,1000 \mathrm{~Hz}$ 의 청력 역치 평균의 차이로 확인하였으며, Balkany 등에 에 의한 청력 보존의 정의에 따라 아래의 3가지로 나누어 분석하 였다. 250, 500, $1000 \mathrm{~Hz}$ 에 해당하는 청력 역치 평균의 악화 가 $10 \mathrm{~dB}$ 이내인 경우 완전 청력 보존(complete hearing preservation), $10 \mathrm{~dB}$ 보다 크나 잔청이 남아있는 경우 부분 청력 보존(partial hearing preservation), 수술 후 잔청이 소실된 경우는 청력소실(none)로 정의하였다.

두 번째 방식(method 2)은 HEARRING group에서 제안한 방식으로 ${ }^{21}$ 수술 전후 상대적인 차이를 이용하는 방식이다:

$$
\begin{aligned}
& \text { Relative change }=\frac{\text { PTApost-PTApre }}{\text { PTAmax-PTApre }} \\
& S=\left[1-\left(\frac{\text { PTApost-PTApre }}{\text { PTAmax-PTApre }}\right)\right] \times 100(\%)
\end{aligned}
$$

PTApost는 술후 순음청력검사 역치 평균, PTApre는 술전 순음청력검사 역치의 평균이고 PTAmax는 청력검사기기 측 정 최대치에 해당한다. $\mathrm{S}$ 는 청력 보존 수치척도(preservation numerical scale)로, $75 \%$ 초과인 경우 완전 청력 보존, $25 \%$ 초과 및 $75 \%$ 이하인 경우 부분 청력 보존, $25 \%$ 이하인 경우 는 최소 청력 보존(minimal hearing preservation), 술후 청 력 소실된 경우는 청력소실(no measurable hearing)으로 정 의하였다.

또한, 수술 전후 주파수별로 해당하는 순음청력검사 역치 의 차이를 전극 기종에 따라 비교 분석하였고, 수술 후 aided WRS에 대한 비교 분석도 진행하였다. 모든 증례에서는 수 술 후 청력 보존을 위해 공통적으로 사용한 약물은 없었다.

\section{통계 분석}

연속적인 데이터는 평균값 및 표준편차로 수치화하여 보고 하였고, 유발복합활동전위 역치, 임피던스는 그래프를 통해 평균표푼편차로 나타냈다. 통계분석으로는 ANOVA 분산 분석 및 독립표본 t검정, Pearson's chi-square 검정을 이용하 였고, 통계적인 유의성은 $p<0.05$ 일 때 유의한 것으로 보았다.

\section{결 과}

\section{대 상}

$\mathrm{CI} 532$ 를 시행 받은 52예 환자들의 수술 당시 평균 나이는 25.8세였고, 난청의 원인과 관련하여 선천성인 경우 34예에 해당하였다. 이외의 원인으로 돌발성 난청 6예, 만성 중이염 2예, 이경화증 1예, 원인 미상 9예가 포함되었다. 선천성 난청 을 제외한 환자들의 평균 난청 기간은 20.9년이었다. CA군과 LW군의 환자와 관련된 인자를 포함한 내용은 Table 1에 기 술하였다. CI532 환자 중 심한 내이 기형이 동반된 증례는 12 예였고(Table 2), 총 52예 중 이 12예를 제외한 40예를 활용하 여 타 모델과의 비교 분석을 진행하였다. 술후 합병증 관련하 여 CA군, LW군 및 CI532군에서 3건, 1건, 2건씩 확인되었다. $\mathrm{CA}$ 군의 경우 기기 고장(device failure) 1 건, 술후 어지럼증 1 건 및 수술부위 부종 1 건이 포함되었고, LW군의 경우 수술 부위 염증 1 건이 있었다. CI532의 경우 와우의 기저부 골성

\begin{tabular}{|c|c|c|c|c|c|c|}
\hline \multirow{2}{*}{ Groups } & \multirow{2}{*}{$\begin{array}{l}\text { Number of } \\
\text { patients }(n)\end{array}$} & \multirow{2}{*}{$\begin{array}{c}\text { Age at implantation } \\
\text { (years) }\end{array}$} & \multirow{2}{*}{$\begin{array}{l}\text { No. of congenital } \\
\text { deafness }(n)\end{array}$} & \multirow{2}{*}{$\begin{array}{l}\text { Deaf duration } \\
\text { (years) }\end{array}$} & \multicolumn{2}{|c|}{ Approaches } \\
\hline & & & & & Round window (n) & Cochleostomy (n) \\
\hline $\mathrm{CA}$ & 40 & $27.3 \pm 24.5$ & 18 & $11.9 \pm 12.5$ & 5 & 35 \\
\hline LW & 39 & $26.1 \pm 25.1$ & 18 & $19.2 \pm 17.8$ & 36 & 3 \\
\hline $\mathrm{Cl} 532$ & $52(40) *$ & $25.8 \pm 25.0$ & $34(22) *$ & $20.9 \pm 13.9$ & 35 & 5 \\
\hline
\end{tabular}

Table 1. Characteristics of the patients and factors related to operations

*number of patients except inner ear anomalies. CA: Contour Advance electrode array group, LW: lateral wall electrode array group 
기형이 있는 환자에서 1건의 잘못된 위치(malposition)를 경 험하였고, 다른 1 건의 경우 수술 부위 염증과 관련한 합병증 이었다.

\section{수술 중 전극 임피던스와 유발복합활동전위}

수술 중 전극 임피던스는 Custom Sound ${ }^{\circledR}$ version 4 소프트 웨어(Cochlear Ltd.)를 이용하였고, ECAP 역치는 AutoNRT ${ }^{\mathrm{TM}}$ 프로그램을 이용하여 측정하였다. 이는 전극 삽입 후에 상처

Table 2. Inner ear anomalies in patients who underwent cochlear implant with $\mathrm{Cl} 532$

\begin{tabular}{lc}
\hline Presence of inner ear anomalies \\
\hline No anatomical abnormalities & 40 \\
IP type II with EVAS & 7 \\
IP type II with BCNC stenosis & 2 \\
BCNC stenosis with cochlear nerve hypoplasia & 2 \\
Vestibular dysplasia with cochlear nerve hypoplasia & 1 \\
\hline IP: incomplete partition, EVAS: enlarged vestibular aqueduct \\
syndrome, BCNC: bony cochlear nerve canal
\end{tabular}

봉합이 종료되기 전 측정이 이루어졌으며, 전극별 임피던스와 ECAP 역치의 평균표준편차는 Figs. 2 and 3에 기술하였 다. 임피던스의 경우 7번, 4번, 3 번 및 2번 전극의 경우 CI532 군에서 $\mathrm{LW}$ 군에 비하여 유의하게 낮은 임피던스 값을 보여주 었다(E07, $p=0.026$; $\mathrm{E} 04, p=0.032 ; \mathrm{E} 03, p=0.031 ; \mathrm{E} 02$, $p=0.032$ ).

$\mathrm{ECAP}$ 역치의 경우는 와우 첨부에 해당하는 22번, 21번, 20 번 및 19번 전극에서 CI532군이 다른 두 군에 비해 모두 유의하게 낮은 역치값을 나타냈고(E22, $p=0.034, p=0.005$; $\mathrm{E} 21, p=0.004, p<0.000$; E20, $p=0.001, p<0.000$; E19, $p<$ $0.000, p<0.000), 18-16$ 번, 11-6번 및 4번 전극에서는 CI532 군이 $\mathrm{LW}$ 군에 비해 의미있게 낮은 역치값을 보였다.

\section{청력 보존}

청력 보존 여부의 비교는 수술 전 저주파수에서의 잔청이 있는 환자를 대상으로 비교를 하였다. 첫 번째 방식(method 1)을 통해 분석한 결과, CI532군의 경우 수술 후 완전 청력

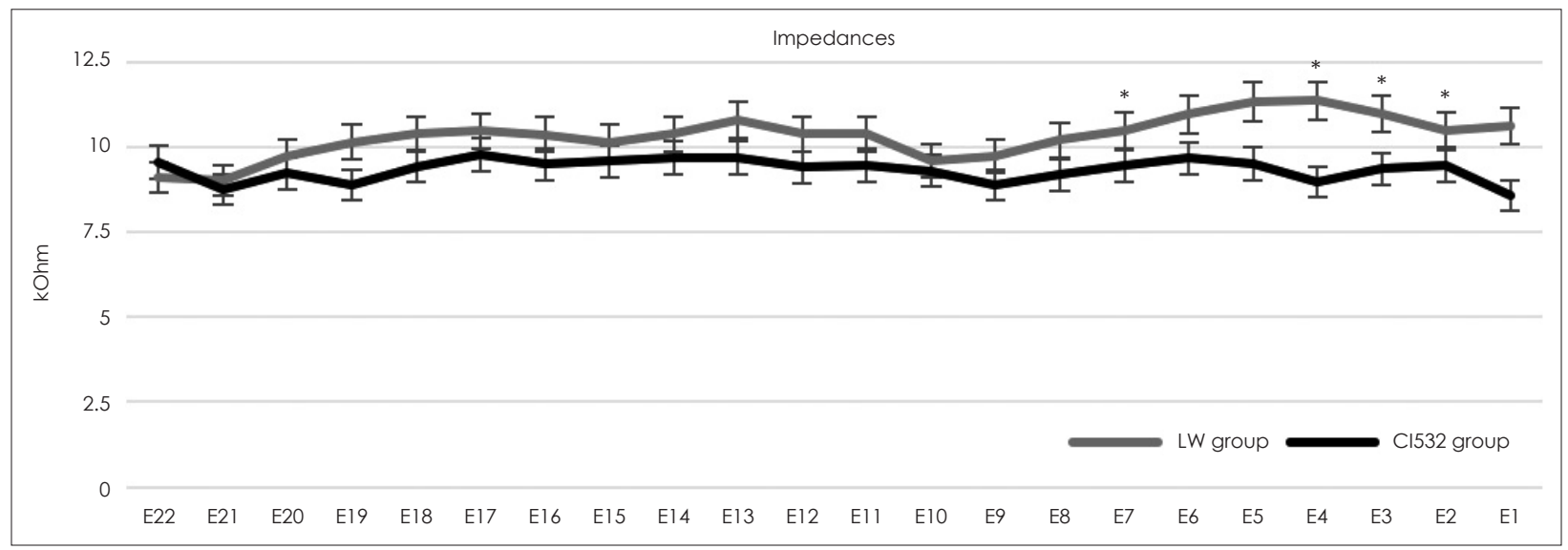

Fig. 2. Intraoperative electrode impedance (kOhm) at each electrode. *significant difference between CI532 and LW group ( $p<0.05)$. LW: lateral wall electrode array group.

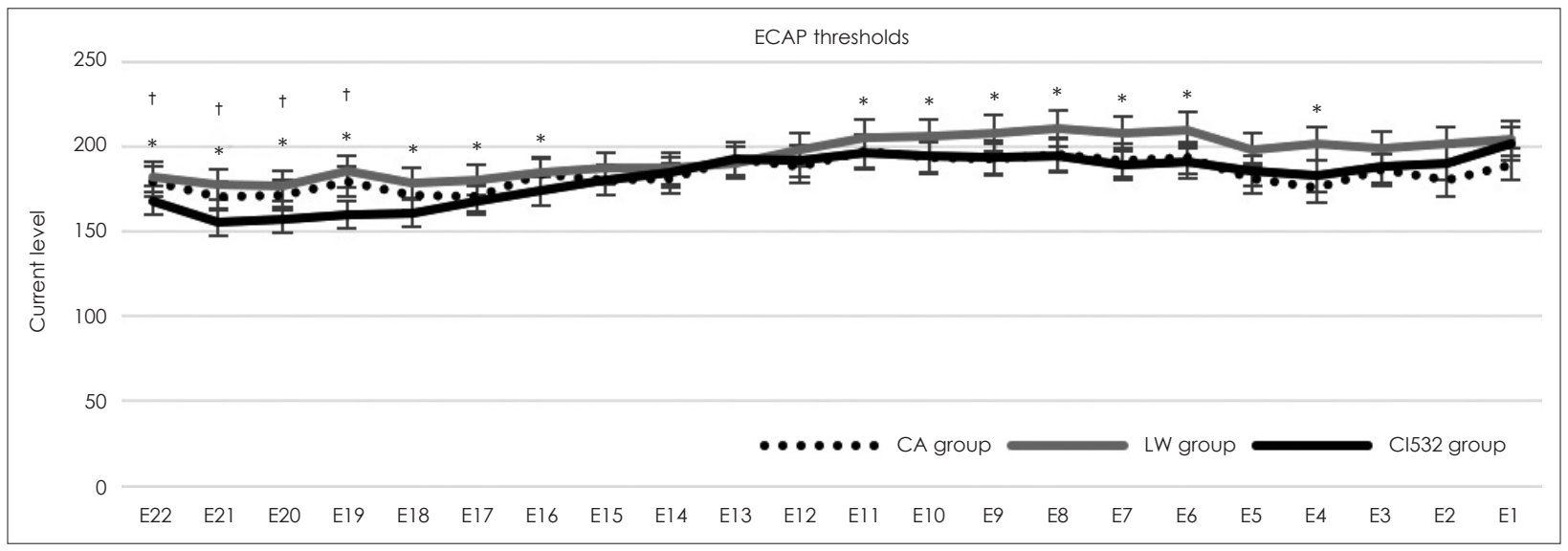

Fig. 3. Intraoperative ECAP threshold at each electrode. * significant difference between $\mathrm{CI} 532$ and CA $(p<0.05)$, tsignificant difference between Cl532 and LW ( $p<0.05)$. ECAP: evoked compound action potential, CA: Contour Advance electrode array group, LW: lateral wall electrode array group. 
보존이 4/12(33.3\%)에 해당하였고, 부분 청력 보존은 5/12 (41.7\%), 잔존 청력이 없는 경우는 3/12(25.0\%)였다. CA군의 경우는 총 18 예 중 1 예만이 완전 청력 보존, 1 예의 부분 청력 보존 결과를 보여주었고, LW군의 경우 청력 보존이 이루어진 경우가 총 12 예 중 2 예의 부분 청력 보존 결과로 나타났으며 이를 통해 CI532군에서 더욱 의미있는 청력 보존이 가능함을 확인할 수 있었다 두 번째 방식(method 2)으로 분석한 결과, CI532군의 경우 수술 후 완전 청력 보존이 3/12(25.0\%), 부 분 청력 보존 $5 / 12(41.7 \%)$, 최소 청력 보존이 $1 / 12(8.3 \%)$, 잔존 청력이 없는 경우는 $3 / 12(25.0 \%)$ 였다. CA군의 경우 총 18 예 중 1 예만이 완전 청력 보존, 1 예의 부분 청력 보존을 보였고, $\mathrm{LW}$ 군은 총 12 예 중 2 예의 부분 청력 보존 결과를 확인할 수 있었다(Table 3).

주파수별 분석을 시행하였을 때, CI532군은 250, 1000, 2000 및 $4000 \mathrm{~Hz}$ 에서 수술 전후 청력 역치값 차이가 LW군 에 비하여 유의하게 낮은 수치를 보였고 $(p=0.021 ; p=0.004$; $p=0.045 ; p=0.013$ )(Fig. 4), CA군의 경우 1000 및 $4000 \mathrm{~Hz}$ 의 주파수에서 $\mathrm{LW}$ 군에 비해 의미있게 낮은 역치값을 보였다 ( $p=0.022 ; p=0.044)$. 그러나, CI532군과 CA군 간에는 유의미 한 차이를 보인 주파수를 확인할 수 없었고, 수술 후 단어인 지점수(aided WRS)의 경우에도 기기 간에 의미 있는 차이를 나타내지 않았다(Table 4).

\section{고 찰}

CI532는 단자 끝이 얇고 유연한 특성 때문에 기존의 다른 기기에 비해서 tip fold-over 발생이 높음이 보고되어 왔다. Aschendorff 등 22 에 따르면 45예 중 2예(4.4\%)에서, McJunkin
등 ${ }^{17)}$ 에 의하면 117 예 중 9예(7.7\%)에서 tip fold-over 경험을 보고한 바 있으며, 이들의 연구는 모두 정상 언어발달이 이루 어진 성인(postlingual adults)을 대상으로 분석을 진행한 것 이었다. 최근의 한 연구에 따르면 ${ }^{23)} 237$ 예 중 11예(4.6\%)의 tip fold-over가 있었는데, 이 중 1건은 Mondini 기형을 동반한 소아의 증례였으며, 이외의 경우는 모두 정상 구조를 가진 환 자에서 발생한 것으로, 수술 중 X-ray를 통한 전극의 적절한 삽입 여부를 확인하는 것이 필요하다고 보고되었다. 본 연구 에서는 52예의 CI532 수술 증례 중 1예(1.9\%)에서 전극의 misplacement를 경험하였고, 이는 tip fold-over가 아닌 전 극이 와우 기저부의 기형에 의해 전정(vestibule)으로 전극이 삽입이 된 증례(malposition)에 해당하였다. 이 환자는 재수 술을 통해 성공적인 전극의 삽입이 가능하였다. 이외의 내이 기형이 동반되지 않는 모든 증례에서는 부작용없이 성공적으 로 수술이 이루어졌다.

수술 중 $\mathrm{ECAP}$ 역치와 임피던스를 통해 전극 단자가 적절 한 부위에 위치하고, 수술시 와우 내부에 어느 정도 손상을 주었는지를 유추할 수 있다. ${ }^{24)}$ 특히 낮은 ECAP 역치값은 각 전극 단자가 와우축(modiolus)에 가깝게 잘 위치하는 것을 시사하는 것으로 알려져 있다. ${ }^{25)}$ 우리의 연구에서는 CI532군 의 $\mathrm{ECAP}$ 역치가 $\mathrm{LW}$ 군과 비교하여서는 와우의 첨부, 중간 부 일부 및 기저부 일부에 걸쳐 의미있게 낮은 역치값을 보이 고, 더욱이 기존의 같은 $\mathrm{PM}$ 형인 $\mathrm{CA}$ 군와 비교하여서도 첨부 에서 더 낮은 역치값을 나타냈다. 이는 CI532이 기존 모델에 비해 첨부까지 보다 가깝게 위치하여 나선형 신경절 섬유 (spiral ganglion fiber)를 자극하는 것이 가능함을 보여준다. 또한, CI532를 이용한 인공와우 환자에서 기저부와 첨부의 ECAP역치의 차이를 비교한 연구에 의하면, ${ }^{1)}$ CI532군에서

Table 3. Hearing preservation after cochlear implantation

\begin{tabular}{|c|c|c|c|}
\hline & $\mathrm{Cl} 532(n=12)^{*+}$ & CA group $(n=18)^{*}$ & LW group $(n=12)$ \\
\hline \multicolumn{4}{|l|}{ Method 1 (\%) } \\
\hline Complete hearing preservation & $4 / 12(33.3)$ & $1 / 18(5.6)$ & - \\
\hline Partial hearing preservation & $5 / 12(41.7)$ & $1 / 18(5.6)$ & $2 / 12(16.7)$ \\
\hline None & $3 / 12(25.0)$ & $16 / 18(88.9)$ & 10/12 (83.3) \\
\hline \multicolumn{4}{|l|}{ Method $2(\%)$} \\
\hline Complete hearing preservation & $3 / 12(25.0)$ & $1 / 18(5.6)$ & - \\
\hline Partial hearing preservation & $5 / 12(41.7)$ & $1 / 18(5.6)$ & $2 / 12(16.7)$ \\
\hline Minimal hearing preservation & $1 / 12(8.3)$ & - & - \\
\hline No measurable hearing & $3 / 12(25.0)$ & $16 / 18(88.9)$ & 10/12 (83.3) \\
\hline
\end{tabular}

Method 1 refers to difference between pre- and postoperative mean thresholds of low-frequencies; complete hearing preservation refers to mean change of low-frequency hearing thresholds of $\leq 10 \mathrm{~dB}$; partial hearing preservation refers to mean change of low-frequency hearing thresholds of $>10 \mathrm{~dB}$ with some residual hearing; none refers to no residual hearing after surgery. Method 2 refers to HEARRING group's formula; complete hearing preservation refers to percent of residual hearing preserved $>75 \%$; partial hearing preservation refers to percent of residual hearing preserved $>25-75 \%$; minimal hearing preservation refers to percent of residual hearing preserved $>0-25 \%$; no measurable hearing refers to no residual hearing after surgery. $* \mathrm{Cl} 532$ vs. CA group, $p<0.002,{ }^{\dagger} \mathrm{Cl} 532$ vs. LW group, $p<0.011$. CA: Contour Advance electrode array group, LW: lateral wall electrode array group 
첨부의 $\mathrm{ECAP}$ 역치가 기저부 역치에 비해 유의하게 낮게 나 오는 결과를 보고한 바 있다. 본 연구에서도 첨부에 해당하 는 전극 부위에 비해 기저부의 전극이 ECAP 역치가 낮은 경 향을 확인할 수 있어 첨부의 전극이 보다 와우축에 가깝게
위치하는 것을 확인할 수 있었다. CI532를 포함한 3종(CI512, CI522 및 CI532)의 기기로 NRT 분석을 진행한 최근의 연구 에서는, ${ }^{26)}$ 우리의 연구와 유사하게 CI532가 전반적인 전극에 서 CI522에 비해 낮은 역치값을 보였고, CI512에 비해서는
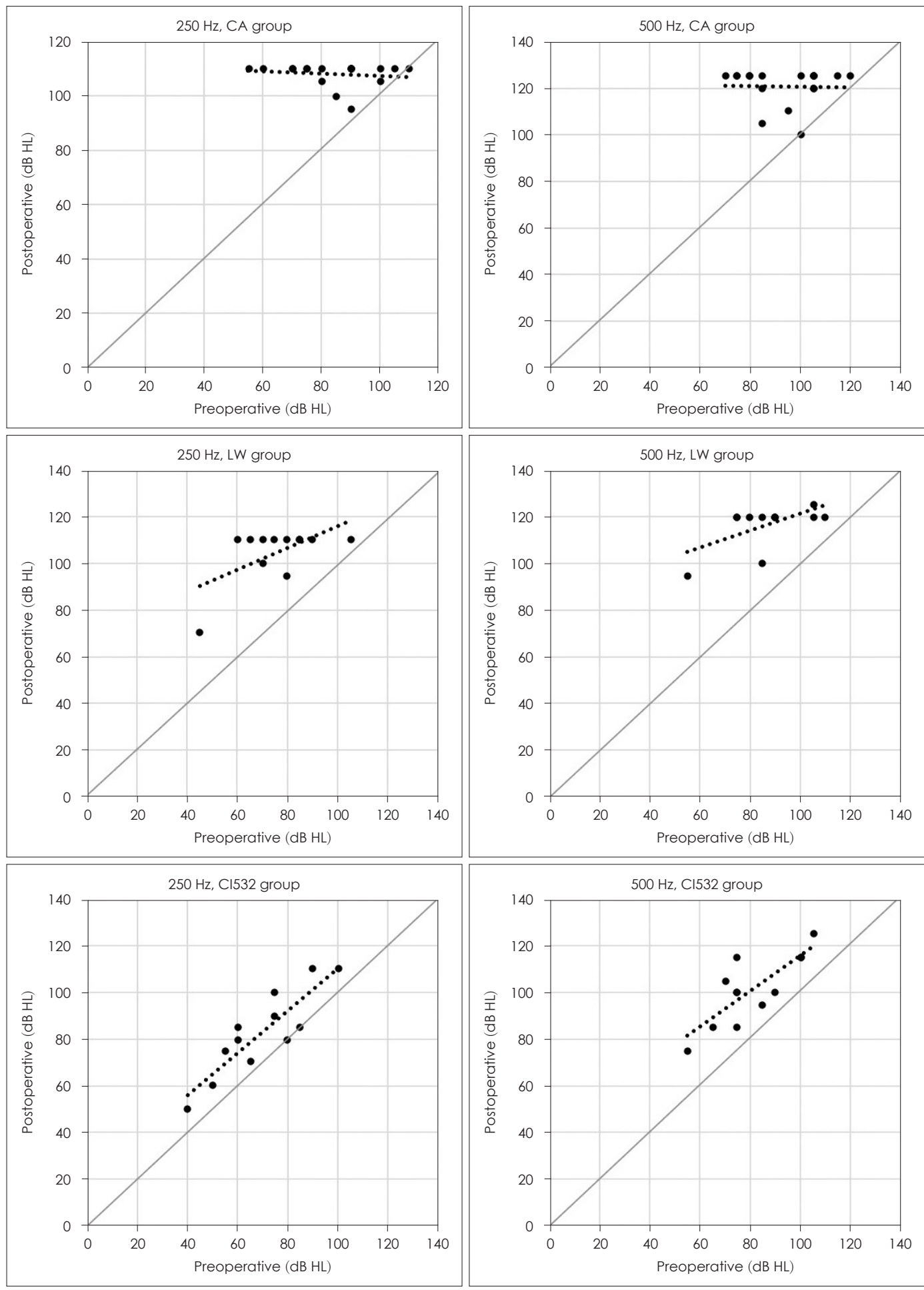

Fig. 4. Comparison of pre- and postoperative hearing thresholds ( $\mathrm{dB} \mathrm{HL}$ ) at 3 months after implantation for CA group (top), LW group (middle), and $\mathrm{Cl} 532$ group (bottom row). $\mathrm{Cl} 532$ group showed well preserved hearing thresholds after $\mathrm{Cl}$ operation. CA: Contour Advance electrode array group, LW: lateral wall electrode array group. 
Table 4. Mean hearing thresholds in 250, 500, 1000, 2000, and $4000 \mathrm{~Hz}$, pre- and postoperatively, and aided WRS

\begin{tabular}{lccc}
\hline Frequencies & CA group & LW group & Cl532 \\
\hline $250 \mathrm{~Hz}$ & & & \\
Preop (dB HL) & $84.2 \pm 15.0$ & $75.8 \pm 15.5$ & $69.6 \pm 17.6$ \\
Postop (dB HL) & $108.1 \pm 4.3$ & $104.6 \pm 12.0$ & $82.9 \pm 18.3$ \\
Difference & $28.9 \pm 16.1$ & $28.8 \pm 12.6^{*}$ & $13.3 \pm 8.9^{*}$ \\
$500 \mathrm{~Hz}$ & & \\
Preop (dB HL) & $93.9 \pm 14.8$ & $87.1 \pm 15.3$ & $80.8 \pm 15.4$ \\
Postop (dB HL) & $120.8 \pm 7.7$ & $116.7 \pm 9.1$ & $101.3 \pm 14.8$ \\
Difference & $26.9 \pm 16.9$ & $29.6 \pm 12.1$ & $20.4 \pm 9.6$ \\
1000 Hz & & & \\
Preop (dB HL) & $108.3 \pm 12.0$ & $94.6 \pm 12.2$ & $100.8 \pm 12.9$ \\
Postop (dB HL) & $123.1 \pm 4.9$ & $122.1 \pm 6.9$ & $111.3 \pm 11.1$ \\
Difference & $14.7 \pm 11.3^{\dagger}$ & $27.5 \pm 14.7^{*}+$ & $10.4 \pm 11.2^{*}$ \\
2000 Hz & & & \\
Preop (dB HL) & $111.4 \pm 12.7$ & $100.0 \pm 13.7$ & $103.8 \pm 12.6$ \\
Postop (dB HL) & $122.2 \pm 6.0$ & $121.3 \pm 5.7$ & $112.1 \pm 13.1$ \\
Difference & $10.8 \pm 11.3$ & $21.3 \pm 15.5^{*}$ & $8.3 \pm 11.7^{*}$ \\
$4000 \mathrm{~Hz}$ & & & \\
Preop (dB HL) & $114.7 \pm 16.0$ & $102.1 \pm 17.4$ & $113.3 \pm 13.5$ \\
Postop (dB HL) & $123.1 \pm 6.2$ & $122.5 \pm 8.7$ & $117.9 \pm 11.2$ \\
Difference & $8.3 \pm 12.6 \dagger$ & $20.4 \pm 17.6^{*+}$ & $4.6 \pm 6.6^{*}$ \\
Aided WRS (\%) & $33.1 \pm 27.6$ & $34.7 \pm 28.3$ & $29.3 \pm 29.6$ \\
\hline
\end{tabular}

*significant difference in postop mean threshold changes between $\mathrm{Cl} 532$ and LW group, $\mathrm{p}<0.05$, tsignificant difference in postop mean threshold changes between CA and LW group, $p<0.05$. CA: Contour Advance electrode array group, LW: lateral wall electrode array group, Preop: preoperative, Postop: postoperative, Difference: difference between pre- and postop hearing thresholds, WRS: word recognition score

$18,14,6$ 번 전극에서 유의하게 낮은 결과값을 나타냈다. 하지 만 이 연구는 모든 전극이 아닌 특정 6 개의 전극 $(22,18,14$, $10,6,2$ 번)에서만 비교 분석을 진행한 것이고, 임피던스 결과 값에 대한 비교는 기술하지 않고 있다.

높은 임피던스 값은 일반적으로 와우의 출혈, 섬유화 및 전 극-조직 간 인터페이스(electrode-tissue interface)가 영향을 미치는 것으로 여겨진다. ${ }^{19,27)} \mathrm{LW}$ 형 전극을 이용한 인공와우 (CI422/522)와 PM형 전극을 이용한 인공와우(CI512)의 임피 던스를 비교 분석한 최근 연구에서, ${ }^{28)} \mathrm{CI} 422 / 522$ 에서 CI512 에 비해 의미있게 높은 비율로 임피던스 spike가 관찰된다고 하였다. 임피던스 spike의 존재는 술후 와우의 염증으로 인한 청력 저하, 현훈 등을 시사할 수 있는 소견으로 본 연구에서 의 상대적으로 높은 임피던스 값과 맥락을 같이 한다고 볼 수 있겠다. 우리의 연구에서는, 기저부에 해당하는 일부 전극 에서 CI532의 임피던스 값이 LW형 모델에 비해 의미있게 낮 은 결과를 보여주었는데, 이는 수술 중 전극 삽입이 시작되는 기저부에서 와우의 손상이 CI532에서 더 적었을 가능성을 나타내며, 특히 와우 내 손상은 전극이 삽입되는 과정에서
가장 많이 발생하는 것으로 보고된다. ${ }^{29,30)}$ 최근의 또다른 연 구에서는 CI532의 임피던스가 CI512에 비해 의미있게 낮은 결과값을 보여주었고, ${ }^{31)}$ 이는 단순히 상대적인 전극 단자의 크기 차이에 의한 결과로 분석하고 있다. 본 연구는 CI532와 CI422/522 일부의 임피던스 결과를 분석한 것으로, 보다 많 은 수의 환자에서의 임피던스 비교 분석이 필요할 것으로 판 단된다.

본 연구에서는 수술 전 잔청이 충분하지 않아 청력 보존을 목적으로 수술한 경우는 매우 드물지만, 최소한으로 와우의 손상을 주는 정도를 비교하는 목적으로 수술 전후에 청력의 변화를 확인하는 분석을 하였다. 현재로서는 잔여 청력의 보 존에 대한 다양한 정의 기준이 있다. 많은 전문가 그룹에서 널리 통용되는 청력 보존 시스템의 필요성을 논하고 있으며, ${ }^{32}$ 수술 전후 순음청력 역치의 차이값을 활용하는 방법이 가장 널리 이용되는 방법으로 알려져 있는데, ${ }^{21)}$ 이 중 본 연구에서 는 Balkany 등 ${ }^{20}$ 에 의한 $250,500,1000 \mathrm{~Hz}$ 에 해당하는 청력 역치 평균의 변화를 확인하는 방법을 포함한 두가지 방법을 이용하였다. Ramos-Macías 등 ${ }^{33)}$ 에 의하면, 수술 3개월 째 “유용한" 청력 보존 $(15 \mathrm{~dB}$ 악화 이내)로 이루어진 경우가 CI532의 경우 90\%(9/10), CI522의 경우 57\%(4/7), 다른 perimodiolar형인 CI512의 경우는 $11 \%(1 / 9)$ 에 해당한다고 보고 하였다. 하지만 이는 3 개월 째의 청력 보존 결과이고, 상기 논 문에서 술후 12 개월 때 청력 보존은 CI532의 경우 5/10(50.0\%), $\mathrm{CI} 522$ 의 경우 $3 / 7(42.9 \%)$ 로 두 기기간 통계적으로 차이를 보 이지는 않았다. 이 연구에서는 CI512 전극에서 상대적으로 낮은 청력 보존 결과를 보인 것에 대해 수술 시 와우개창술 을 사용한 것의 영향을 들고 있다. 본 연구에서 와우개창술 접근법을 이용한 경우가 $\mathrm{CA}$ 군에서 $87.5 \%(35 / 40), \mathrm{CI} 532$ 에서 $12.5 \%(5 / 40)$ 으로, $\mathrm{CA}$ 군에서 와우개창술 접근법을 많이 사 용하여 의미있게 청력 보존이 적은 결과를 보이는 것을 설명 할 수 있는 유사한 연구로 생각된다. 이에 반해 본 연구의 CI422/522 경우, $10.0 \%(4 / 40)$ 에서만 와우개창술 접근법으로 수술을 시행하여 CI532군과 유사한 수술 술식으로 진행되었 음에도 술후 잔존 청력 보존은 유의미한 차이를 보임에 따라 본 연구를 통해서는 수술 술식에 비해 전극의 길이와 형태도 술후 청력 보존과 관련이 있을 것으로 생각된다. Lenarz 등 ${ }^{44}$ 에 따르면, 잔여 청력의 보존은 전극의 길이와 유연성(flexibility) 및 비외상성의 수술 기술(atraumatic surgical technique)에 의해 가능하다고 하였다. 청력 보존과 전극 길이 간 에 상관관계에 있어서는 짧은 전극이 청력이 더 보존된다는 연구 결과가 있는데, ${ }^{35,36)} \mathrm{PM}$ 형의 경우 일반적으로 와우 고실 계의 측벽에 위치하는 $\mathrm{LW}$ 형과 비교하여 보다 와우의 내측에 위치하므로 전체 길이가 더 짧은 경향이 있다. $\mathrm{PM}$ 군인 $\mathrm{CA}$ 와 
CI532의 경우, 전극의 첨부의 끝(tip) 부분부터 기저부에 마 지막으로 삽입되는 전극까지의 길이가 $14.4 \mathrm{~mm}$ 인 반면, $\mathrm{LW}$ 형태인 CI422 및 CI522의 경우 각각 $20.0 \mathrm{~mm}, 19.1 \mathrm{~mm}$ 의 길이를 가지는 것으로 보고된다. ${ }^{23)}$

수술 전 청력역치에서 얼마나 청력역치가 나빠졌는지(일반 적으로 청력역치의 변화가 없거나 $10 \mathrm{~dB}$ 이내로 나빠질 경우 청력 보존이 된 것으로 판단)에 따라 청력 보존 여부를 결정 하는 기존의 방법들과는 달리 최근 HEARRING group에서 는 수술 전후 청력도의 상대적인 차이를 보는 방식을 제시하 고 있다. ${ }^{21)}$ 이는 수술 전후 청력 역치의 변화를, 청력검사 기기 최대 측정치와 술전 청력 역치의 차이(최대한 나빠질 수 있는 청력의 범위)로 나눈 상대적인 값을 이용하는 것으로 잔여 청력 정도를 백분율(\%)로 파악할 수 있는 장점이 있다. 따라 서, 같은 정도로 청력이 악화될 경우, 잔청이 많이 남아있을 경우 청력 보존이 상대적으로 잘된 것으로 판단되고, 잔청이 거의 없는 환자에서는 청력 보존이 잘 안되는 것으로 판단되 는 경향이 있다. 본 연구의 술전 잔여 청력이 있는 환자를 대 상으로 HEARRING group의 방식을 적용해 본 결과 CI532 군에서 완전 청력 보존 3/12(25.0\%), 부분 청력 보존 5/12 (41.7\%), 최소 청력 보존 $1 / 12(8.3 \%)$, 잔존 청력이 없는 경우 3/12(25.0\%)의 유사한 결과를 보였고, CA 및 LW군에서는 앞선 방식과 동일한 결과를 보여주었다.

CI532 단일기기에서의 청력 보존과 관련하여 몇몇 연구들 에서 그 결과를 보고하고 있다. ${ }^{23,37)}$ Friedmann 등 ${ }^{23)}$ 에 의하 면, $39.5 \%$ 의 환자에서 $250,500 \mathrm{~Hz}$ 청력역치의 평균이 $80 \mathrm{~dB}$ 보다 좋게 보존된다고 보고하였고, $\mathrm{Cuda}$ 등 $^{37)}$ 은 수술 전후 청 력역치 변화가 $10 \mathrm{~dB}$ 전후로 보존되어 CI532 의 삽입 외상이 최소화됨을 강조하고 있다. Ramos-Macias 등 ${ }^{33}$ 에 의하면 125 부터 $750 \mathrm{~Hz}$ 에 해당하는 청력역치에서 수술 전후 청력 보존에 대해 기기별로 기술하고 있으나, 통계적인 유의성에 대해서는 고찰하지 않고 있다. 본 연구를 통해서도 저음역대 에 해당하는 $250 \mathrm{~Hz}$ 주파수 대역에서 CI532는 LW군에 비해 청력 보존이 유의미하게 더 많이 이루어졌음을 확인할 수 있 었고 $\mathrm{CA}$ 군에 비해서도 청력 보존이 비교적 잘 이뤄졌으나 통 계적으로 의미있는 결과를 나타내지는 못하였다 $(p=0.102)$

(Fig. 4).

그러나, 인공와우수술을 통한 청력 개선을 확인할 수 있는 가장 중요한 지표인 어음인지능력은 이러한 기기에 따른 수술 후 3 개월째 검사한 어음인지력에는 큰 차이를 보이지 않아, 이러한 임피던스나 ECAP 역치의 차이에 의한 임상적인 언어 인지능력의 차이에 미치는 영향이 크지는 않을 것으로 생각 된다. 그러나, 어음인지력의 발달이 초기에 많이 발달하지만 수년에 걸쳐 점차적으로 발전하므로 보다 장기적인 언어인지
능력의 관찰이 필요할 것으로 생각된다.

본 연구에는 몇 가지 한계점을 가지고 있다. 첫 번째로 환 자군의 수가 많지 않다는 점이다. CI532로 명시한 기간 내에 수술 시행한 것은 총 52예가 있으나, 심한 내이 기형을 동반한 환자는 제외하고 40 예를 분석한 것이라 더 많은 증례가 요구 되는 바이다. 두 번째로 PM형 모델인 CI512가 CA에 비교하 여 보다 최신 모델이나, 최근에는 CI512보다는 CI532를 주로 사용하게 되어 CI512의 증례가 부족하여, 기존의 PM 모델인 $\mathrm{CA}$ 를 이용하여 비교 분석에 활용하게 되었다. 세 번째로 수 술장 내 전극 임피던스 분석에서 기존의 데이터가 모두 존재 하지 않아 CA군과의 비교가 불가능했던 점이다. 네 번째, 수 술 기법 중 와우접근법에 있어 정원창 접근법을 확장과 비확 장으로 구분하지는 않았다. 수술시 확장 정원창 접근법을 활 용하는 경우 와우에 손상을 더 가져올 수 있고 이는 수술 중 $\mathrm{ECAP}$ 결과 및 술후 잔여 청력 보존 결과에도 영향을 미칠 수 있는 부분으로 판단된다. 마지막으로 본 연구는 CI532의 국내에서의 단기 결과를 분석한 것이라 술후 3 개월까지의 분 석 결과에 해당한다. 향후 보다 많은 환자에서의 장기간의 수 술 결과 및 분석이 요구된다.

CI532 slim perimodiolar 전극은 기존 전극 모델과 비교하 여 수술장 내에서 시행한 ECAP 역치 및 임피던스가 더 낮은 결과를 보여주었고, 수술 후 잔여 청력의 보존에 있어 기존의 전극에 비해 우수한 결과를 보여주고, 저음역대 청력 보존 또 한 가능한 것으로 나타났다. 그러나, 가장 중요한 단어인지능 력에서는 큰 차이를 보이지 않아 향후 추가적인 연구를 통해 장기적인 언어인지능력의 향상에 차이가 있는지 검증하는 과 정이 요구된다.

\section{Acknowledgments}

None.

\section{Author Contribution}

Conceptualization: all authors. Data curation: Jin Taek Park, Min Young Kwak, Yehree Kim, Jee Yeon Lee. Formal analysis: Jin Taek Park, Min Young Kwak, Yehree Kim, Jee Yeon Lee, Hong Ju Park. Supervision: Woo Seok Kang, Jha, Jong Woo Chung, Hong Ju Park. Writing - original draft: Jin Taek Park, Min Young Kwak, Yehree Kim, Jee Yeon Lee, Hong Ju Park. Writing — review \& editing: Jin Taek Park, Min Young Kwak, Yehree Kim, Jee Yeon Lee, Woo Seok Kang, Jha, Jong Woo Chung, Hong Ju Park.

\section{ORCID}

Hong Ju Park

https://orcid.org/0000-0002-6331-8556

\section{REFERENCES}

1) Hey M, Wesarg T, Mewes A, Helbig S, Hornung J, Lenarz T, et al. Objective, audiological and quality of life measures with the CI532 Slim Modiolar electrode. Cochlear Implants Int 2019;20(2):80-90.

2) Lazard DS, Vincent C, Venail F, Van de Heyning P, Truy E, Sterkers 
O, et al. Pre-, per- and postoperative factors affecting performance of postlinguistically deaf adults using cochlear implants: A new conceptual model over time. PLoS One 2012;7(11):e48739.

3) Kim LS, Lee MY, Heo MJ, Oh YJ. Long-term development of auditory performance in children with cochlear implants. Korean J Otolaryngol-Head Neck Surg 2002;45(1):18-21.

4) Kim JR, Shin BS. The relationship between electrically evoked compound action potential and speech perception in CI24RE implant users. Korean J Otorhinolaryngol-Head Neck Surg 2010;53(8):470-4.

5) Lehnhardt E. [Intracochlear placement of cochlear implant electrodes in soft surgery technique]. HNO 1993;41(7):356-9.

6) Park S, Choi JY. A case of electric acoustic stimulation cochlear implantation in partial deafness with residual low-frequency hearing. Korean J Otorhinolaryngol-Head Neck Surg 2012;55(11):712-6.

7) Jang $\mathrm{JH}$, Lee SH. Updates in prognostic factors of cochlear implantation. Korean J Otorhinolaryngol-Head Neck Surg 2014; 57(11):738-47.

8) Jeong J, Kim M, Heo JH, Bang MY, Bae MR, Kim J, et al. Intraindividual comparison of psychophysical parameters between perimodiolar and lateral-type electrode arrays in patients with bilateral cochlear implants. Otol Neurotol 2015;36(2):228-34.

9) Lathuillière M, Merklen F, Piron JP, Sicard M, Villemus F, Menjot de Champfleur N, et al. Cone-beam computed tomography in children with cochlear implants: The effect of electrode array position on ECAP. Int J Pediatr Otorhinolaryngol 2017;92:27-31.

10) Wackym PA, Firszt JB, Gaggl W, Runge-Samuelson CL, Reeder RM, Raulie JC. Electrophysiologic effects of placing cochlear implant electrodes in a perimodiolar position in young children. Laryngoscope 2004;114(1):71-6

11) Patrick JF, Busby PA, Gibson PJ. The development of the Nucleus Freedom Cochlear implant system. Trends Amplif 2006;10(4):175200.

12) Ahn JH, Oh SH, Chung JW, Lee KS. Facial nerve stimulation after cochlear implantation according to types of Nucleus 24-channel electrode arrays. Acta Otolaryngol 2009;129(6):588-91.

13) Wanna GB, Noble JH, Carlson ML, Gifford RH, Dietrich MS, Haynes DS, et al. Impact of electrode design and surgical approach on scalar location and cochlear implant outcomes. Laryngoscope 2014;124 Suppl 6(0 6):S1-7.

14) Kim YR, Yoo MH, Lee JY, Yang CJ, Park JW, Kang BC, et al. Characteristics and pathogenesis of facial nerve stimulation after cochlear implant surgeries: A single-centre retrospective analysis from 1151 patients. Clin Otolaryngol 2018;43(5):1396-400.

15) Briggs RJ, Tykocinski M, Lazsig R, Aschendorff A, Lenarz T, Stöver T, et al. Development and evaluation of the modiolar research array--multi-centre collaborative study in human temporal bones. Cochlear Implants Int 2011;12(3):129-39.

16) Park LR, Teagle HFB, Brown KD, Gagnon EB, Woodard JS, Buchman CA. Audiological outcomes and map characteristics in children with perimodiolar and slim straight array cochlear implants in opposite ears. Otol Neurotol 2017;38(9):e320-6.

17) McJunkin JL, Durakovic N, Herzog J, Buchman CA. Early outcomes with a slim, modiolar cochlear implant electrode array. Otol Neurotol 2018;39(1):e28-33.

18) van Dijk B, Botros AM, Battmer RD, Begall K, Dillier N, Hey M, et al. Clinical results of AutoNRT, a completely automatic ECAP recording system for cochlear implants. Ear Hear 2007;28(4):558-70.

19) Venail F, Mura T, Akkari M, Mathiolon C, Menjot de Champfleur S, Piron JP, et al. Modeling of auditory neuron response thresholds with cochlear implants. Biomed Res Int 2015;2015:394687.

20) Balkany TJ, Connell SS, Hodges AV, Payne SL, Telischi FF, Eshraghi AA, et al. Conservation of residual acoustic hearing after cochlear implantation. Otol Neurotol 2006;27(8):1083-8.

21) Skarzynski H, van de Heyning P, Agrawal S, Arauz SL, Atlas M, Baumgartner $\mathrm{W}$, et al. Towards a consensus on a hearing preservation classification system. Acta Otolaryngol Suppl 2013;(564):3-13.

22) Aschendorff A, Briggs R, Brademann G, Helbig S, Hornung J, Lenarz T, et al. Clinical investigation of the Nucleus Slim Modiolar electrode. Audiol Neurootol 2017;22(3):169-79.

23) Friedmann DR, Kamen E, Choudhury B, Roland JT Jr. Surgical experience and early outcomes with a slim perimodiolar electrode. Otol Neurotol 2019;40(3):e304-10.

24) Gordon KA, Papsin BC. From nucleus 24 to 513: Changing cochlear implant design affects auditory response thresholds. Otol Neurotol 2013;34(3):436-42.

25) Gordin A, Papsin B, James A, Gordon K. Evolution of cochlear implant arrays result in changes in behavioral and physiological responses in children. Otol Neurotol 2009;30(7):908-15.

26) Perenyi A, Toth F, Dimak B, Nagy R, Schoerg P, Jori J, et al. Electrophysiological measurements with electrode types of different perimodiolar properties and the same cochlear implant electronics - a retrospective comparison study. J Otolaryngol Head Neck Surg 2019;48(1):46.

27) Clark GM, Shute SA, Shepherd RK, Carter TD. Cochlear implantation: Osteoneogenesis, electrode-tissue impedance, and residual hearing. Ann Otol Rhinol Laryngol Suppl 1995;166:40-2.

28) Shaul C, Bester CW, Weder S, Choi J, Eastwood H, Padmavathi $\mathrm{KV}$, et al. Electrical impedance as a biomarker for inner ear pathology following lateral wall and peri-modiolar cochlear implantation. Otol Neurotol 2019;40(5):e518-26.

29) Kawano A, Seldon HL, Clark GM, Ramsden RT, Raine CH. Intracochlear factors contributing to psychophysical percepts following cochlear implantation. Acta Otolaryngol 1998;118(3): 313-26.

30) Nadol JB Jr, Eddington DK, Burgess BJ. Foreign body or hypersensitivity granuloma of the inner ear after cochlear implantation: One possible cause of a soft failure? Otol Neurotol 2008;29(8):1076-84.

31) Cuda D, Murri A. Assessment of cochlear trauma and telemetry measures after cochlear implantation: A comparative study between Nucleus ${ }^{\circledR}$ CI512 and CI532 electrode arrays. Audiol Res 2019;9(1): 223.

32) Skarzynski H, van de Heyning P, DeMin H, Li Y, Bo L, Caversaccio M, et al. Hearing Preservation Classification. J Hear Sci 2012;2(2): 95-6.

33) Ramos-Macías A, Borkoski-Barreiro SA, Falcón-González JC, Ramos-de Miguel A. Hearing preservation with the Slim Modiolar Electrode Nucleus $\mathrm{CI} 532^{\circledR}$ cochlear implant: a preliminary experience. Audiol Neurootol 2017;22(6):317-25.

34) Lenarz T, Stöver T, Buechner A, Lesinski-Schiedat A, Patrick J, Pesch J. Hearing conservation surgery using the Hybrid-L electrode. Results from the first clinical trial at the Medical University of Hannover. Audiol Neurootol 2009;14 Suppl 1:22-31.

35) Gantz BJ, Dunn C, Oleson J, Hansen M, Parkinson A, Turner C. Multicenter clinical trial of the Nucleus Hybrid S8 cochlear implant: Final outcomes. Laryngoscope 2016;126(4):962-73.

36) Roland JT Jr, Gantz BJ, Waltzman SB, Parkinson AJ; Multicenter Clinical Trial Group. United States multicenter clinical trial of the cochlear nucleus hybrid implant system. Laryngoscope 2016; 126(1):175-81.

37) Cuda D, Murri A. Cochlear implantation with the Nucleus Slim Modiolar electrode (CI532): A preliminary experience. Eur Arch Otorhinolaryngol 2017;274(12):4141-8. 